\title{
Nanogels from Metal-Chelating Crosslinkers as Versatile Platforms Applied to Copper-64 PET Imaging of Tumors and Metastases
}

\author{
Jacques Lux ${ }^{1^{*}}$, Alexander G. White $2^{*}$, Minnie Chan ${ }^{1}$, Carolyn J. Anderson ${ }^{2 \bowtie}$, Adah Almutairi1 ${ }^{1 \rrbracket}$ \\ 1. Skaggs School of Pharmacy and Pharmaceutical Sciences, and the Laboratory of Bioresponsive Materials, University of California, San \\ Diego. 9500 Gilman Dr. 0600, La Jolla, CA 92093-0600, United States. \\ 2. University of Pittsburgh Departments of Radiology, Pharmacology \& Chemical Biology and Bioengineering. Molecular Imaging Labor- \\ atory, 100 Technology Drive, Pittsburgh, PA 15219, United States. \\ 3. KACST-UCSD Center for Excellence in Nanomedicine and Engineering
}

*These authors contributed equally.

$\square$ Corresponding authors: Prof. Adah Almutairi. E-mail: aalmutairi@ucsd.edu. Prof. Carolyn Anderson. E-mail: andersoncj@upmc.edu.

() Ivyspring International Publisher. This is an open-access article distributed under the terms of the Creative Commons License (http://creativecommons.org/ licenses/by-nc-nd/3.0/). Reproduction is permitted for personal, noncommercial use, provided that the article is in whole, unmodified, and properly cited.

Received: 2014.10.24; Accepted: 2014.12.03; Published: 2015.01.01

\begin{abstract}
Metals are essential in medicine for both therapy and diagnosis. We recently created the first metal-chelating nanogel imaging agent, which employed versatile, reproducible chemistry that maximizes chelation stability. Here we demonstrate that our metal chelating crosslinked nanogel technology is a powerful platform by incorporating ${ }^{64} \mathrm{Cu}$ to obtain PET radiotracers. Polyacrylamide-based nanogels were crosslinked with three different polydentate ligands (DTPA, DOTA, NOTA). NOTA-based nanogels stably retained ${ }^{64} \mathrm{Cu}$ in mouse serum and accumulated in tumors in vivo as detected by PET/CT imaging. Measurement of radioactivity in major organs ex vivo confirmed this pattern, revealing a high accumulation $(12.3 \% \mathrm{ID} / \mathrm{g}$ and $16.6 \% \mathrm{ID} / \mathrm{g})$ in tumors at 24 and $48 \mathrm{~h}$ following administration, with lower accumulation in the liver $(8.5 \% \mathrm{ID} / \mathrm{g}$ at $24 \mathrm{~h}$ ) and spleen $(5.5 \% \mathrm{ID} / \mathrm{g})$. Nanogels accumulated even more efficiently in metastases $(29.9 \%$ and $30.4 \% \mathrm{ID} / \mathrm{g}$ at 24 and $48 \mathrm{~h}$ ). These metal-chelating nanogels hold great promise for future application as bimodal PET/MRI agents; chelation of $\beta$-emitting radionuclides could enable radiation therapy.
\end{abstract}

Key words: Nanogels, metal-chelating crosslinkers, copper 64, PET, NOTA, preclinical imaging, metastases.

\section{Introduction}

Metal complexes have an important role in medicine and are used clinically in various imaging modalities[1] such as magnetic resonance imaging (MRI), $[2,3]$ positron emission tomography (PET) $[4,5]$ and X-ray imaging.[6] A system enabling incorporation of various metals would serve as a versatile platform for the development of multifunctional agents combining imaging modalities and radiotherapy. For this purpose, we decided to incorporate metal chelators into hydrogel nanoparticles, or nano- gels. These nanoscale systems have high stability in aqueous media, $[7,8]$ high loading capacity for small molecules[9, 10] and larger biomolecules[11, 12] and allow facile access of water throughout the particle, which is a key feature in the development of MRI contrast agents. In our previous study, metal-chelating crosslinkers were chelated with $\mathrm{Gd}^{3+}$ to yield MRI contrast agent nanogels with improved safety relative to other Gd-chelated nanoscale agents.[13] In addition to chelating with paramagnetic 
$\mathrm{Gd}^{3+}$, this strategy allows us to formulate metal-free nanogels containing crosslinkers that can be readily chelated with radiometals prior to biological studies, which avoids additional decay before clinical use. Another advantage of having metal chelates within particles is that the nanogel surface stays available for further functionalization with molecularly targeted ligands. To demonstrate the versatility of our platform and take advantage of another capability of metals in medicine, here we incorporate ${ }^{64} \mathrm{Cu}$ to access PET imaging.

Because nanoparticles allow longer circulation time, passive accumulation in tumors and inflamed tissues and active targeting of specific cell types via conjugation of surface ligands, nanoscale PET imaging agents have attracted much attention in recent years.[14-28] Copper-64 is a promising isotope for PET because of its suitable half-life (12.7 hours) and unique decay characteristics $\left(\beta^{+}(656 \mathrm{keV}, 17.4 \%)\right.$ and $\beta$ - $(573 \mathrm{keV}, 38.5 \%))$. Nanoscale PET agents incorporating ${ }^{64} \mathrm{Cu}$ into gold nanoparticles without the use of chelators have recently been reported by Liu and coworkers;[26] however, their preparation is not likely to be compatible with clinical translation because they incorporate ${ }^{64} \mathrm{Cu}$ by alloying with gold, so surface chemistry for immune evasion and targeting would have to be performed post-labeling, shortening the time frame for imaging studies. ${ }^{64} \mathrm{Cu}$-doped quantum dots, recently introduced by Chen and coworkers, [27] face the same limitation, in addition to the questionable biocompatibility of CdSe.[29] Such strategies are not easily adapted to the incorporation of other metals or to encapsulate drugs, limiting their utility to PET.

The simple yet elegant platform described here enables incorporation of a variety of metals in addition to ${ }^{64} \mathrm{Cu}$, including $\mathrm{Gd}$ for MRI and ${ }^{177} \mathrm{Lu}$ for therapy to yield multimodal or theranostic agents. This chelator-crosslinked strategy not only is amenable to most chelation system, but enables straightforward functionalization with PEG or targeting moieties prior to radiolabeling. Moreover it has been reported that the stability of copper chelates is enhanced upon incorporation within a nanostructure, thus limiting the risk of toxicity.[21, 22] Welch, Wooley and coworkers, for example, reported the radiolabeling of their shell-crosslinked nanoparticles (SCKs) with various ${ }^{64} \mathrm{Cu}$-chelating agents.[14, 15, 22] Even more promising is the demonstration by Hawker and coworkers that a natriuretic peptide receptor-targeted polymeric nanoparticle radiolabeled with ${ }^{64} \mathrm{Cu}$-DOTA detects prostate cancer with high sensitivity and good pharmacokinetics;[24] this agent is now being translated for imaging patients with cardiovascular disease.
Only one other example of radiolabeled chemically crosslinked nanogels for PET imaging has been reported;[30] however, their size $(290 \pm 50 \mathrm{~nm})$ may not provide optimal circulation time and tumor uptake.[31] More importantly, radiolabel stability and in vivo PET/CT imaging of radiolabeled nanogels have not yet been examined.

Here we report the first ${ }^{64} \mathrm{Cu}$-labeled chelator crosslinked nanogels for tumor imaging by passive accumulation through the enhanced permeation and retention (EPR) mechanism. Three metal-chelating crosslinkers were screened to identify the chelation platform that most stably retains ${ }^{64} \mathrm{Cu}$. It was shown by Meares et al. in the mid 1980's that macrocyclic chelators are required for stable retention of copper radionuclides in vivo,[32] as acyclic chelators such as DTPA release copper radionuclides within minutes after i.v. injection.[33] To determine whether the nanogels would enhance stability of $\mathrm{Cu}$ (II) chelates, we initially investigated a DTPA-based crosslinker. Additionally we evaluated a previously reported crosslinker based on DOTA, as well as a novel NOTA-based structure. Nanogels crosslinked with these polydentate ligands were chelated with ${ }^{64} \mathrm{Cu}$ and their complexation stability was evaluated in mouse serum. The most stable PET imaging agents were then evaluated by PET/CT imaging in BALB/c mice with subcutaneous $4 \mathrm{~T} 1$ tumors or metastases induced by intravenous injection of $4 \mathrm{~T} 1$ cells.

\section{Results and Discussion}

Three metal-chelating crosslinkers, 1, 2, and 3, based on diethylenetriaminepentaacetic acid (DTPA), 1,4,7,10-tetraazacyclododecane-1,4,7,10-tetraacetic

acid (DOTA) and 1,4,7-triazacyclononane-1,4,7triacetic acid (NOTA), respectively (Figure 1) were investigated.

The DTPA-based crosslinker $\mathbf{1}$ was synthesized in three steps (Figure 2), beginning with acrylation of the N-Boc-1,3-propanediamine under Schotten-Baumann conditions (two-phase solvent system), followed by deprotection of the Boc protecting group to give 5. Finally, DTPA dianhydride was reacted with 5 to give the DTPA-based crosslinker $\mathbf{1}$. The $C$-substituted protected DOTA derivative 6 was obtained in 4 steps following the literature procedure (Figure 2).[34] In parallel, the bisacrylamide derivative 7 was synthesized in one step from the commercial 3,5-diaminobenzoic acid under the same conditions used for the preparation of 4 . The synthesis of the DOTA-based crosslinker 2 was reported previously.[13] The C-substituted NOTA crosslinker derivative was synthesized in five steps (Figure 2). The first step of this synthesis was protection of 3,5-dinitroaniline with Fmoc-chloride. The two nitro 
functions of the resulting protected aniline 9 were then reduced in the presence of tin chloride dihydrate in quantitative yield. The diamino compound $\mathbf{1 0}$ was acrylated under the same conditions used for the preparation of 4 and 7, and the bisacrylamide compound $\mathbf{1 1}$ was deprotected in the presence of piperi- dine. The target NOTA crosslinker 3 was finally obtained via an isothiocyanate-amine coupling between the bisacrylamide compound $\mathbf{1 2}$ and the commercially available NOTA macrocycle $p$-benzyl isothiocyanate derivative.

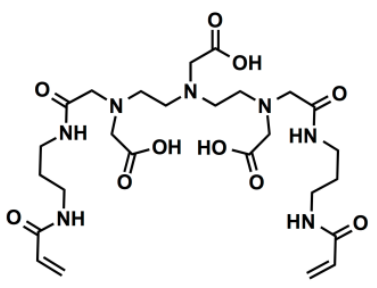

1

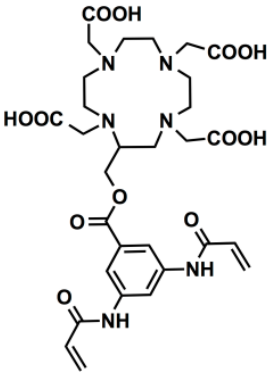

2

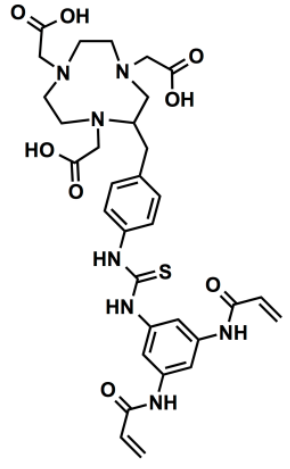

3

Figure 1. Chemical structures of the three metal-chelating crosslinkers.

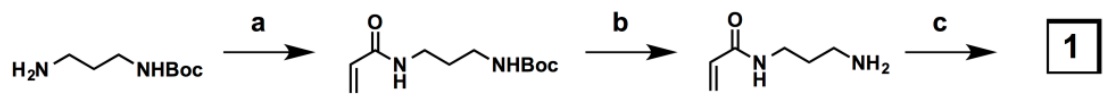

4

5

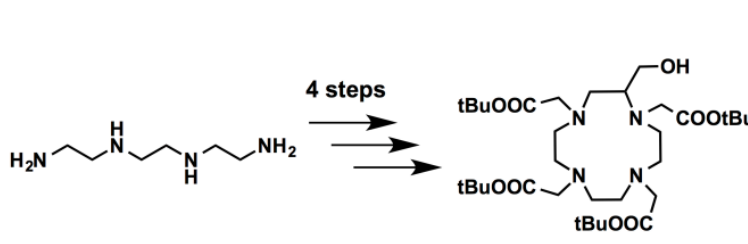

6<smiles>C=CC(=O)Nc1cc(NC(=O)C=C)cc(C(=O)O)c1</smiles>

7

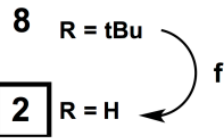

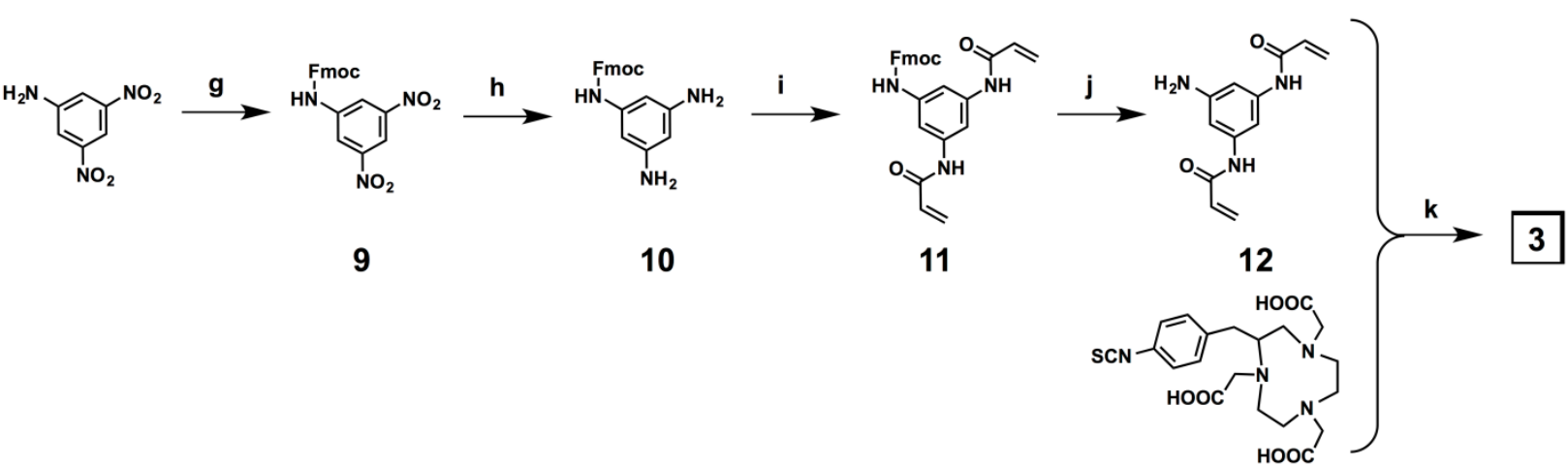

Figure 2. Synthesis of the metal-chelating crosslinkers 1, 2, and 3. a) Acryloyl chloride, $\mathrm{K}_{2} \mathrm{CO}_{3}$, EtOAc/ $/ \mathrm{H}_{2} \mathrm{O}, 0^{\circ} \mathrm{C}$ to r.t., $16 \mathrm{~h}, 100 \%$; b) TFA/DCM, r.t., $30 \mathrm{~min}, 100 \%$; c) DTPA dianhydride, $\mathrm{Et}_{3} \mathrm{~N}$, r.t., $50 \%$; d) acryloyl chloride, $\mathrm{K}_{2} \mathrm{CO}_{3}$, $\mathrm{EtOAc} / \mathrm{H}_{2} \mathrm{O}, 0^{\circ} \mathrm{C}$ to r.t., 100 min, $84 \%$; e) DCC, DMAP, DCM, $0{ }^{\circ} \mathrm{C}$ to r.t., 48 h, $59 \%$; f) TFA/DCM 1:1, r.t., 16 h, $100 \%$; g) Fmoc-Cl, THF- $10 \%$ AcOH 1:1, r.t., 20 h, $39 \%$; h) $\mathrm{SnCl}_{2}$. $\left(\mathrm{H}_{2} \mathrm{O}\right)_{2}$, EtOH, $70{ }^{\circ} \mathrm{C}, 18 \mathrm{~h}, 100 \%$; i) Acryloyl chloride, $\mathrm{K}_{2} \mathrm{CO}_{3}$, $\mathrm{EtOAc} / \mathrm{H}_{2} \mathrm{O}, 0{ }^{\circ} \mathrm{C}$ to r.t., $30 \mathrm{~min}, 100 \%$; j) piperidine, DMF, r.t., 4 h, $52 \%$; k) $\mathrm{Et}_{3} \mathrm{~N}, \mathrm{MeOH}$, r.t., 48 h, $59 \%$. 
The metal-chelating crosslinkers 1, 2, and $\mathbf{3}$ were then used to prepare polyacrylamide (PAA) nanogels. PAA was selected to constitute the nanogel backbone because it is non-toxic and stable.[35-37] Though PAA is not biodegradable, the hydrogel nanoparticle will degrade over time through enzymatic hydrolysis of the crosslinker amide bonds, allowing clearance of metal chelates; the remaining polyacrylamide would be slowly metabolized.[38] Polyacrylamide-based nanocarriers have also been shown to enhance tumor uptake of imaging probes.[39] Polyacrylamide-based nanogels PAA/1, PAA/ 2 and PAA/ $\mathbf{3}$ were prepared by inverse emulsion polymerization of acrylamide with crosslinker $\mathbf{1}, \mathbf{2}$, or $\mathbf{3}$ using ammonium persulfate (APS) as the initiator and adding tetramethylethylenediamine (TMEDA) to control the radical polymerization rate (Figure 3). Using dynamic light scattering (DLS), nanogels PAA/1, PAA/ $\mathbf{2}$ and PAA/3 were found to have hydrodynamic diameters of $65 \mathrm{~nm}, 56 \mathrm{~nm}$, and $63 \mathrm{~nm}$ with PDI of $0.37,0.22$ and 0.43 and $\zeta$-potentials of $-15.8,-7.2$, and $-8.9 \mathrm{mV}$, respectively, were measured (Supplementary Material: Figure S1). Following nanogel formulation, incorporated crosslinkers were chelated with $37 \mathrm{MBq}(1 \mathrm{mCi})$ ${ }^{64} \mathrm{Cu}$ per $100 \mu \mathrm{g}$ of nanogels at $70{ }^{\circ} \mathrm{C}$ for $2 \mathrm{~h}$ in PBS (pH 7.4). Excess ${ }^{64} \mathrm{Cu}$ was removed using a centrifugal concentrator with a 3000 Da cutoff.

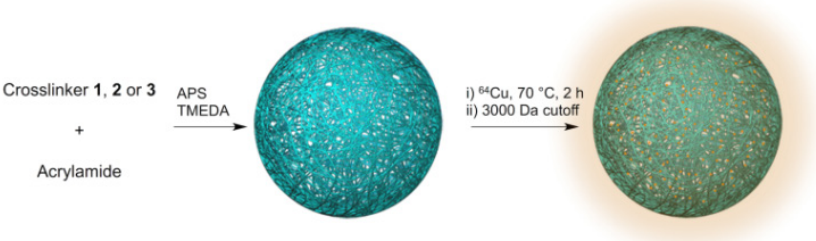

Figure 3. Preparation of nanogels through inverse emulsion process and ${ }^{64} \mathrm{Cu}$ labeling of the crosslinkers.

To translate these imaging platforms into clinical practice, radiolabeled nanogels must stably chelate ${ }^{64} \mathrm{Cu}$ to prevent any leakage of radionuclide, which would be retained in the blood and liver. Stability of ${ }^{64} \mathrm{Cu}$-labeled nanogels toward transchelation was evaluated in PBS in the absence or presence of EDTA (ethylenediaminetetraacetic acid) (Supplementary Material: Figure S2). To identify the best candidate for in vivo imaging, stability experiments were also performed in mouse serum (Figure 4). The three nanogels were added to the corresponding solutions, incubated at $37{ }^{\circ} \mathrm{C}$ and monitored via radio-TLC at different time points using $\mathrm{MeOH}: \mathrm{NH}_{4} \mathrm{OAc}(75: 25)$ as the running solution to measure the Relative amounts of radioactive copper in ${ }^{64} \mathrm{Cu}$-chelated nanogels and ${ }^{64} \mathrm{Cu}$-EDTA. In the presence of EDTA and serum,
DTPA-based nanogels retained ${ }^{64} \mathrm{Cu}$ poorly, with only $11 \%$ of the ${ }^{64} \mathrm{Cu}$ remaining chelated to PAA/ 1 after 1 h. DOTA-based nanogels (PAA/2) chelated copper more stably in mouse serum, retaining $87 \%$ at $1 \mathrm{~h}$ and $69 \%$ at $48 \mathrm{~h}$ (Figure 4). Cu-DOTA complexes are generally unstable for longer periods of time in vivo;[40] however, placing DOTA chelators within a nanostructure increases the stability of the ${ }^{64} \mathrm{Cu}$-DOTA complex.[21, 22] This explains the relative stability of PAA $/ 2\left({ }^{64} \mathrm{Cu}\right)$ in mouse serum. As expected, the NOTA-based nanogel PAA/3 $\left({ }^{64} \mathrm{Cu}\right)$ was the most stable, retaining $94 \%$ of chelated ${ }^{64} \mathrm{Cu}$ at $1 \mathrm{~h}$ and $91 \%$ at 24 and $48 \mathrm{~h}$ in mouse serum (Figure 4 ). As $\mathrm{Cu}^{2+}$ can be trapped in polyacrylamide-based nanogels,[41] the $9 \%$ loss of copper from NOTA nanogels may represent the portion trapped in the network that was not chelated by the crosslinkers. To evaluate the amount of copper trapped in the polyacrylamide backbone, polyacrylamide nanogels lacking metal-chelating crosslinkers were labeled with ${ }^{64} \mathrm{Cu}$; these nanogels retained only $5 \%$ as much ${ }^{64} \mathrm{Cu}$ as that in nanogels containing metal-chelating crosslinkers (data not shown).

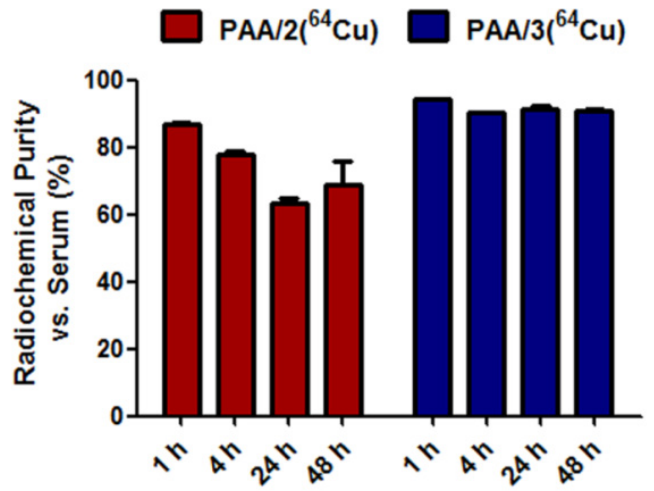

Figure 4. Stability of ${ }^{64} \mathrm{Cu}$-labeled PAA/2 $\left({ }^{64} \mathrm{Cu}\right)$ and $\mathrm{PAA} / 3\left({ }^{64} \mathrm{Cu}\right)$ nanogels in mouse serum. PAA $/ 1\left({ }^{64} \mathrm{Cu}\right)$ retained only $11 \%$ of the chelated ${ }^{64} \mathrm{Cu}$ and therefore was not included.

Due to the instability of DTPA-based PAA $/ 1\left({ }^{64} \mathrm{Cu}\right)$ nanogels in mouse serum $\left(11 \%{ }^{64} \mathrm{Cu}\right.$ retention at $1 \mathrm{~h}$ ), only the ${ }^{64} \mathrm{Cu}$-chelated DOTA- and NOTA-based nanogels PAA $/ 2\left({ }^{64} \mathrm{Cu}\right)$ and PAA $/ 3\left({ }^{64} \mathrm{Cu}\right)$ were selected for in vivo imaging. As tumors are known to contain leaky vasculature, allowing accumulation of nanoparticles between 10 and $400 \mathrm{~nm}$ in diameter, we expected passive tumor accumulation even without addition of targeting moieties.[5, 8, 19] BALB/c mice containing subcutaneous 4T1 murine mammary carcinoma tumors were injected with $\sim 6.6 \mathrm{MBq}(180 \mu \mathrm{Ci})$ of PAA/ $2\left({ }^{64} \mathrm{Cu}\right)$ or $\mathrm{PAA} / 3\left({ }^{64} \mathrm{Cu}\right)$ via the tail vein (Figure 5$)$. Though tumor cells were implanted subcutaneously in both cases, there is a small chance that differing locations 
might have affected uptake. After $4 \mathrm{~h}$, accumulation of PAA $/ 3\left({ }^{64} \mathrm{Cu}\right)$ was visible in the heart, liver, and blood vessels in the neck, while a moderate amount of signal was visualized in the tumor. PAA $/ 2\left({ }^{64} \mathrm{Cu}\right)$ showed a similar pattern of uptake at $4 \mathrm{~h}$, but with higher accumulation in the liver. After $24 \mathrm{~h}$, uptake of PAA $/ 3\left({ }^{64} \mathrm{Cu}\right)$ in the tumor increased to $5.5 \% \mathrm{ID} / \mathrm{g}$ (percent injected dose per gram) and continued to increase to $6.95 \% \mathrm{ID} / \mathrm{g}$ at $48 \mathrm{~h}$. PAA $/ 2\left({ }^{64} \mathrm{Cu}\right)$ showed a similar trend, however, the uptake of $4 \% \mathrm{ID} / \mathrm{g}$ and $4.3 \% \mathrm{ID} / \mathrm{g}$ at 24 and $48 \mathrm{~h}$, respectively, were lower than PAA/3 $\left({ }^{64} \mathrm{Cu}\right)$.
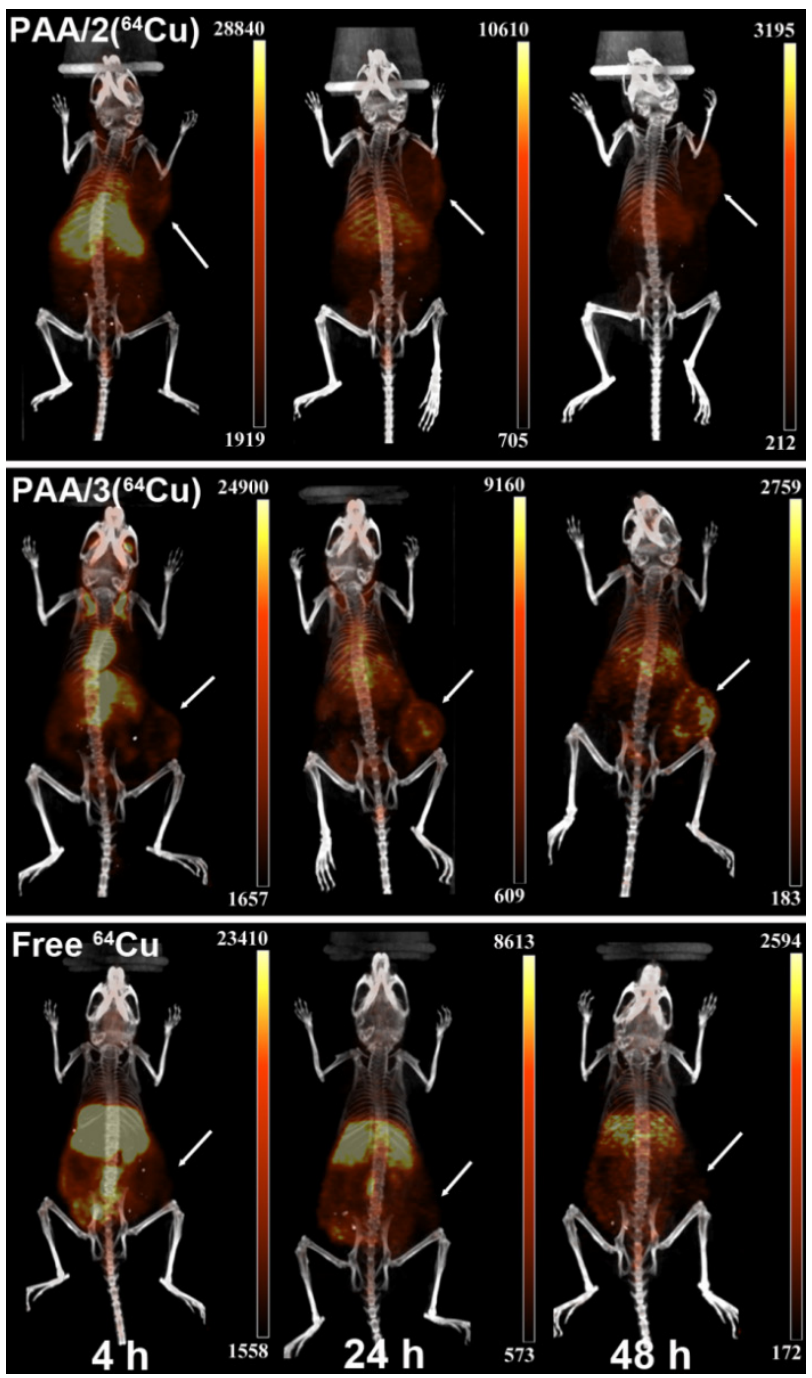

Figure 5. PET/CT images comparing uptake of PAA/2 $\left({ }^{64} \mathrm{Cu}\right)$ and PAA/3 $\left({ }^{64} \mathrm{Cu}\right)$ nanogels to free ${ }^{64} \mathrm{Cu}$ in mice containing subcutaneous $4 \mathrm{~T} 1$ murine mammary carcinoma tumors $\left(n=3\right.$ for PAA $/ 2(64 \mathrm{Cu}), n=2$ for PAA $/ 3\left({ }^{64} \mathrm{Cu}\right)$, and $n=5$ for free ${ }^{64} \mathrm{Cu}$ ). Mice were injected with $\sim 6.6 \mathrm{MBq}$ of nanogel or $\sim 6.4 \mathrm{MBq}$ of free ${ }^{64} \mathrm{Cu}$ and imaged at $4 \mathrm{~h}, 24 \mathrm{~h}$, and $48 \mathrm{~h}$ post injection. White arrows indicate tumors. Images are scaled in $\mathrm{nCi} / \mathrm{cc}$ and windowed based on both the injected dose and the decay of ${ }^{64} \mathrm{Cu}$ to adequately depict uptake of injected material into tumors over time.

As free copper can be taken up by tumors via copper transporters,[42] we compared tumor uptake of $\mathrm{PAA} / 2\left({ }^{64} \mathrm{Cu}\right)$ and $\mathrm{PAA} / 3\left({ }^{64} \mathrm{Cu}\right)$ to that of
${ }^{64} \mathrm{Cu}$-acetate. While tumor uptake of free ${ }^{64} \mathrm{Cu}(\sim 6.4$ MBq $(175 \mu \mathrm{Ci}))$ at $4 \mathrm{~h}$ was comparable to that of both nanogel systems, it remained unchanged at 24 and 48 $\mathrm{h}$ (Figure 5). The difference in uptake patterns between nanogels and free copper suggest that ${ }^{64} \mathrm{Cu}$ uptake following nanogel administration does not result from free copper uptake via copper transporters.

Uptake of PAA/2 $\left({ }^{64} \mathrm{Cu}\right), \mathrm{PAA} / 3\left({ }^{64} \mathrm{Cu}\right)$ and free copper was quantified by region-of-interest (ROI) analysis using \% ID/g tumor as a measure of probe uptake (Figure 6). Tumor accumulation of PAA/3 $\left({ }^{64} \mathrm{Cu}\right)$ increased from $2.9 \% \mathrm{ID} / \mathrm{g}$ at $4 \mathrm{~h}$ to 6.95 at $48 \mathrm{~h}$ while that of PAA/ $2\left({ }^{64} \mathrm{Cu}\right)$ tumors increased from 2.9 at $4 \mathrm{~h}$ to 4.27 at $48 \mathrm{~h}$ (Supplementary Material: Table S1). Conversely, free copper within tumors remained steady at $\sim 3 \% \mathrm{ID} / \mathrm{g}$ throughout the experiment. In addition, heart uptake of PAA/ $2\left({ }^{64} \mathrm{Cu}\right)$ and PAA $/ 3\left({ }^{64} \mathrm{Cu}\right)$ was higher than that of free copper at all time points and decreased over time at a rate similar to that of tumor accumulation, suggesting removal of the nanogels from circulation. The greater heart uptake of PAA $/ 3\left({ }^{64} \mathrm{Cu}\right)$ than PAA $/ 2\left({ }^{64} \mathrm{Cu}\right)$ is further evidence of the greater stability of NOTA-based nanogel systems. To normalize for variance between animals, tumor-to-muscle (T/M) ratios were compared among cohorts. While $\mathrm{T} / \mathrm{M}$ ratios for PAA/2 $\left({ }^{64} \mathrm{Cu}\right)$ and $\mathrm{PAA} / 3\left({ }^{64} \mathrm{Cu}\right)$ at $4 \mathrm{~h}$ were only slightly greater than those of free copper, they were significantly greater at both later time points. The $\mathrm{T} / \mathrm{M}$ ratio of $\mathrm{PAA} / 3\left({ }^{64} \mathrm{Cu}\right)$ was significantly higher than that of PAA/ $\left.2{ }^{64} \mathrm{Cu}\right)(\mathrm{p} \leq 0.01)$ at $48 \mathrm{~h}$.

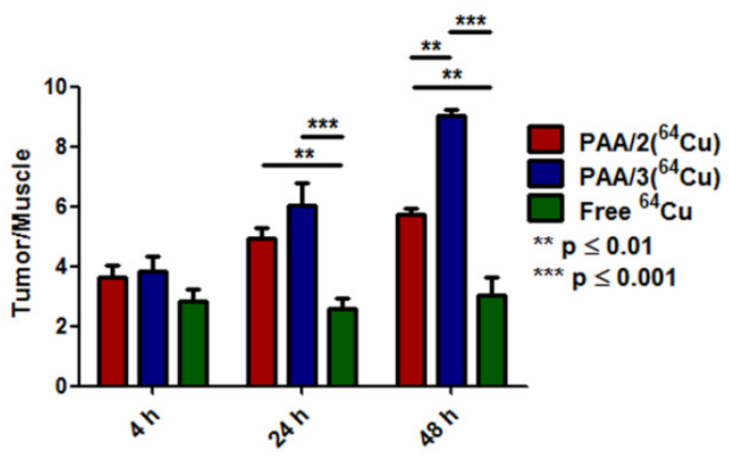

Figure 6. ROI analysis comparing tumor uptake over time of PAA/2 $\left({ }^{64} \mathrm{Cu}\right)$ and $\mathrm{PAA} / 3\left({ }^{64} \mathrm{Cu}\right)$ to free ${ }^{64} \mathrm{Cu}$ in $\mathrm{BALB} / \mathrm{c}$ mice containing $4 \mathrm{~T} 1$ tumors $(\mathrm{n}=3$ for PAA $/ 2\left({ }^{64} \mathrm{Cu}\right), n=2$ for PAA $/ 3\left({ }^{64} \mathrm{Cu}\right)$, and $n=5$ for free $\left.{ }^{64} \mathrm{Cu}\right) . \%$ ID/g values of tumor and muscle tissue were used to calculate ratios, with error bars indicating standard error of the mean. Significance was tested using 2-way ANOVA with a Bonferroni post-test.

To test the nanogels' imaging performance in a more biologically relevant system, we injected 100,000 4T1-luc cells directly into the bloodstream of BALB/c mice. This serves as a model of metastasis without having to grow and remove a primary tumor, while retaining the primary tumor's genetic profile.[43] The 
injected cells were stably transfected with firefly luciferase to enable monitoring by bioluminescence imaging. Metastases formed on the shoulders of both mice and in the left popliteal lymph node of one mouse. Both mice were injected with PAA $/ 3\left({ }^{64} \mathrm{Cu}\right)$, and PET imaging was performed 24 and $48 \mathrm{~h}$ after injection, as these time points showed highest uptake in subcutaneous tumor imaging. At both 24 and $48 \mathrm{~h}$, PAA $/ 3\left({ }^{64} \mathrm{Cu}\right)$ co-localized with bioluminescent signal (Figure 7). Although PAA/3 $\left({ }^{64} \mathrm{Cu}\right)$ performed in a very similar manner as in the subcutaneous tumor imaging studies, the nanogels accumulated to a greater degree in metastases than in subcutaneous tumors $(29.9$ and $26.1 \% \mathrm{ID} / \mathrm{g}$ at $24 \mathrm{~h}$, and 30.6 and $30.4 \% \mathrm{ID} / \mathrm{g}$ at $48 \mathrm{~h}$ in shoulder metastases and 17.1 and $20.5 \%$ ID/g at 24 and $48 \mathrm{~h}$ in the lymph node lesion). Remaining uptake of PAA/3 $\left({ }^{64} \mathrm{Cu}\right)$ was in the liver, heart, and main blood vessels in the neck, indicating similar pharmacodynamics as in the subcutaneous tumor model. The difference in uptake between primary tumors and metastases is likely attributable to necrosis in primary tumors. Uptake of nanogels was only visualized in the periphery, while it was more uniform in smaller metastatic tumors, likely due to greater vascularity and less necrosis. As region-of-interest analysis includes all tumor tissue, the lack of uptake in necrotic regions of the tumor would account for differences in uptake.
To obtain more detailed data on pharmacokinetics and nanogel stability, biodistribution of DOTAand NOTA-crosslinked nanogels was assessed by measuring radioactivity of various organs (Figure 8). We hypothesized that the in vitro stability of PAA $/ 3\left({ }^{64} \mathrm{Cu}\right)$ against EDTA and mouse serum would correlate with lower ${ }^{64} \mathrm{Cu}$ uptake in the liver compared to PAA $/ 2\left({ }^{64} \mathrm{Cu}\right)$. At $4 \mathrm{~h}$ post-injection, $\sim 15 \%$ $\mathrm{ID} / \mathrm{g}$ of both ${ }^{64} \mathrm{Cu}$-labeled nanogels was detected within the blood, indicating resistance to immediate uptake by clearance organs (Figure 8A). While tumor accumulation of the nanogels at $4 \mathrm{~h}$ did not differ, accumulation of PAA/3 $\left({ }^{64} \mathrm{Cu}\right)$ in the liver was significantly lower than that of PAA $/ 2\left({ }^{64} \mathrm{Cu}\right)(8.18 \% \mathrm{ID} / \mathrm{g}$ vs. $12.4 \% \mathrm{ID} / \mathrm{g} ; \mathrm{p} \leq 0.01)$, indicating greater stability against transchelation as early as $4 \mathrm{~h}$ post injection. Tumor uptake did not differ between the two nanogels at $24 \mathrm{~h}$ post-injection; the increase relative to $4 \mathrm{~h}$ agrees with the PET imaging data (Figure 8B). Increased tumor accumulation correlated with decreased blood activity (T/B ratio of 2.2 for PAA $/ 2\left({ }^{64} \mathrm{Cu}\right)$ and 1.5 for PAA $/ 3\left({ }^{64} \mathrm{Cu}\right)$ at $24 \mathrm{~h}$ vs. 0.25 at $4 \mathrm{~h})$. Liver uptake of PAA $/ 3\left({ }^{64} \mathrm{Cu}\right)$ remained constant from 4 to $24 \mathrm{~h}$, whereas that of PAA/2 $\left({ }^{64} \mathrm{Cu}\right)$ increased, further indicating enhanced stability of NOTA-containing nanogel systems in vivo ( $\mathrm{p} \leq 0.01$ between PAA $/ 2\left({ }^{64} \mathrm{Cu}\right)$ and PAA $\left./ 3\left({ }^{64} \mathrm{Cu}\right)\right)$.

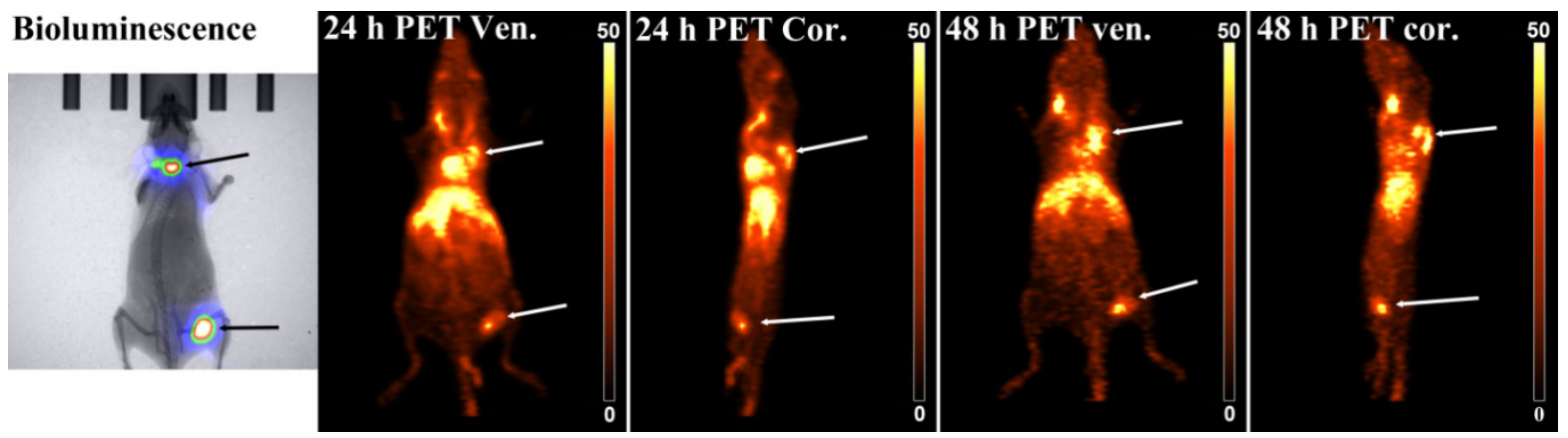

Figure 7. Bioluminescence and PAA/3 $\left({ }^{64} \mathrm{Cu}\right)$ PET images of a mouse bearing 4T1-luc tumors in the shoulder and popliteal lymph node of the leg. Mice were injected with $29.25 \mathrm{MBq}$ of nanogel and imaged at $24 \mathrm{~h}$ and $48 \mathrm{~h}$ post-injection. White arrows show tumors in PET/CT image and black arrows indicate tumors in the bioluminescence image. PET/CT images are scaled and windowed to \%ID/g as indicated on the calibration bar $(n=2)$.
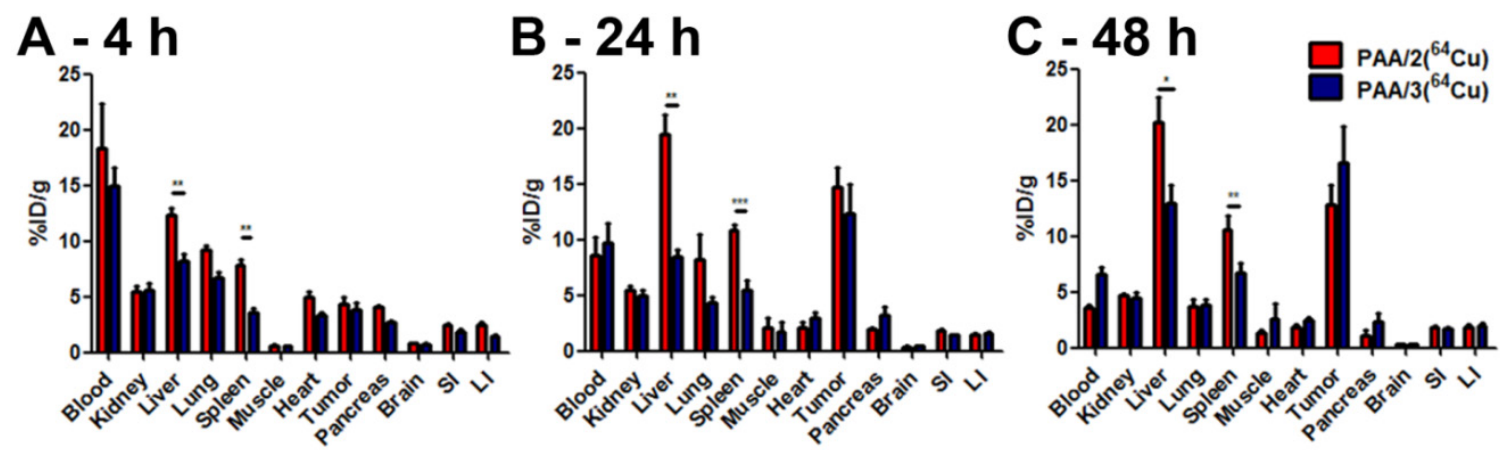

Figure 8. Biodistribution analysis of nanogel systems PAA/2 $\left({ }^{64} \mathrm{Cu}\right)$ [red bars] and PAA/3 $(64 \mathrm{Cu})$ [blue bars] in BALB/c mice containing subcutaneous $4 T 1$ murine mammary carcinoma tumors. Nanogel uptake was evaluated by harvesting organs at [A] $4 \mathrm{~h},[\mathrm{~B}] 24 \mathrm{~h}$, and [C] $48 \mathrm{~h}$ post injection and assaying the $64 \mathrm{Cu}$ radioactivity in a gamma counter. $\mathrm{n}=5$ for each nanogel type at each time point. Error bars indicate standard error of the mean. Statistical analysis employed a two-tailed t-test. $*=p \leq 0.05, * *=p \leq 0.01, * * *=p \leq 0.001$. 
At $48 \mathrm{~h}$, both ${ }^{64} \mathrm{Cu}$-labeled nanogels cleared from the blood, with a corresponding increase in the tumor/blood ratio (3.5 for PAA/2 $\left({ }^{64} \mathrm{Cu}\right)$ and 2.5 for PAA $/ 3\left({ }^{64} \mathrm{Cu}\right)$ ) (Figure 9). Tumor uptake of PAA $/ 3\left({ }^{64} \mathrm{Cu}\right)$ increased to $16.6 \% \mathrm{ID} / \mathrm{g}$ while that of PAA $/ 2\left({ }^{64} \mathrm{Cu}\right)$ decreased to $12.9 \%$ ID/g (Figure $8 \mathrm{C}$ ); this difference was not statistically significant. Liver uptake of PAA $/ 3\left({ }^{64} \mathrm{Cu}\right)$ was significantly lower than that of PAA/ $2\left({ }^{64} \mathrm{Cu}\right)(\mathrm{p} \leq 0.05)$, as was that in the spleen $(p \leq 0.01)$ (Figure 8 and 9B).

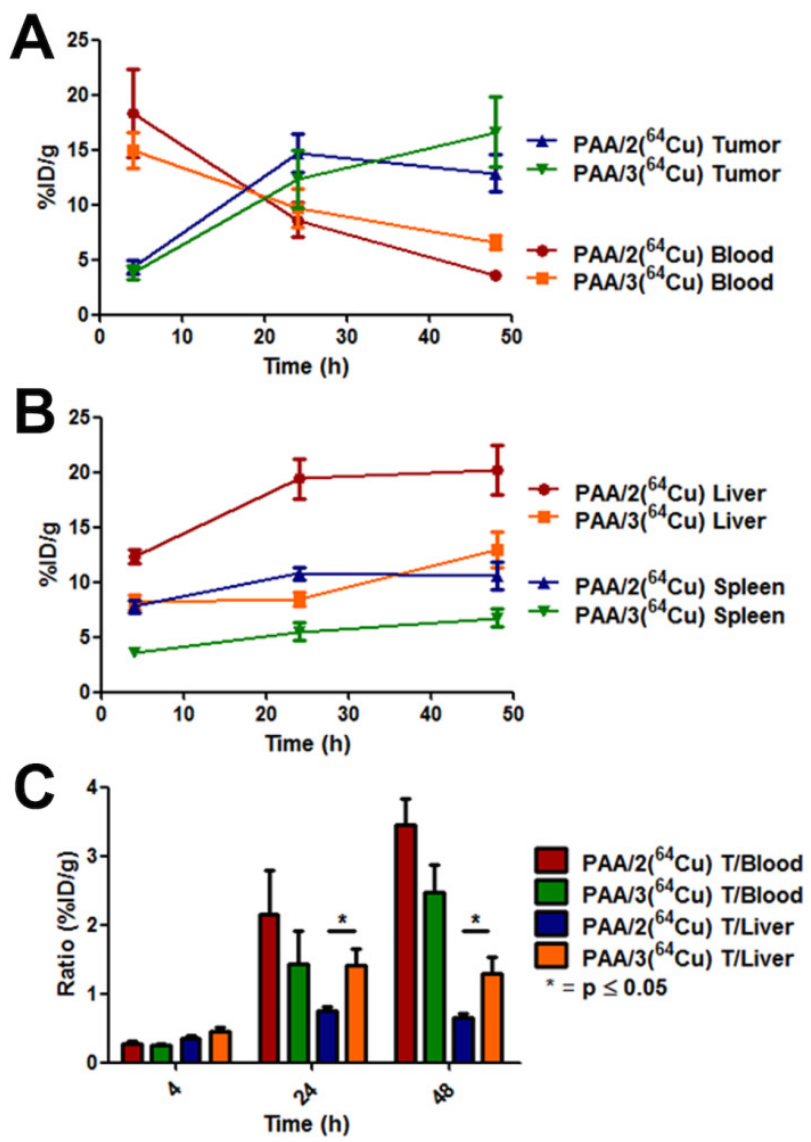

Figure 9. Pharmacokinetic curves from biodistribution of PAA/2 $\left({ }^{64} \mathrm{Cu}\right)$ and PAA/3 $\left({ }^{64} \mathrm{Cu}\right)$. [A] Curves evaluating tumor uptake and blood clearance of nanogel systems. [B] Curves showing uptake of nanogels inside the liver and spleen. [C] Tumor-to-blood and tumor-to-liver ratios of respective nanogel systems calculated from \%ID/g values. Nanogel uptake was evaluated by harvesting organs at $4 \mathrm{~h}, 24 \mathrm{~h}$, and $48 \mathrm{~h}$ post injection and assaying the ${ }^{64} \mathrm{Cu}$ radioactivity in a gamma counter. $n=5$ for each nanogel type at each time point. Error bars are indicative of standard error of the mean.

Although DOTA will stably complex many +3 radiometals, including $\mathrm{Ga}(\mathrm{III})$ and $\mathrm{Lu}(\mathrm{III})$, it is not ideal for $\mathrm{Cu}(\mathrm{II})$, which dissociates in vivo and readily binds to proteins such as superoxide dismutase, ceruloplasmin, and metallothionein.[44] It is because of this lability of $\mathrm{Cu}(\mathrm{II})$ compared to +3 metals that thermodynamic stability is not as relevant as kinetic stability, and therefore in vivo stability is the criterion used to judge effective chelating agents for copper radionuclides.[45] When conjugated to proteins and nanoparticles, the tertiary structure has been shown to protect the $\mathrm{Cu}$ (II)-DOTA complex, yielding greater in vivo stability.[21, 46] The lower stability of ${ }^{64} \mathrm{Cu}-\mathrm{DOTA}$ vs ${ }^{64} \mathrm{Cu}-\mathrm{NOTA}$ nanogels (PAA/2 and PAA/3, respectively) suggests that exposed DOTA chelators on the nanogel surface are subject to transchelation. The NOTA chelator stably complexes ${ }^{64} \mathrm{Cu}(\mathrm{II})$, and ${ }^{64} \mathrm{Cu}$-labeled bioconjugates with NOTA analogs have been reported to have favorable target tissue uptake and rapid clearance. [47, 48] Our data confirm the superior in vivo stability of NOTA vs. DOTA chelators, and indicate that PAA/ 3 is an attractive platform for delivery of copper radionuclides for PET $\left({ }^{64} \mathrm{Cu}\right)$ or targeted radiotherapy $\left({ }^{67} \mathrm{Cu}\right)$ of cancer and other diseases.

The data presented here describe a novel type of hydrogel nanoparticle with considerable potential as a scaffold for metals in imaging or drug delivery, especially within oncology. [26, 49] Tumor uptake of our nanogels (12-14\% ID/g in a subcutaneous tumor at 24 $\mathrm{h}$ post-injection and 26.1 to $30.6 \% \mathrm{ID} / \mathrm{g}$ for metastases) are very comparable to that of PEGylated gold nanoparticles directly incorporating ${ }^{64} \mathrm{CuCl}_{2}$ into the particle core as reported by Zhao et al. ( $13 \%$ ID/g), ${ }^{26}$ and greater than that of PEGylated gold nanorods synthesized by Wang et al. incorporated DOTA chelating groups for ${ }^{64} \mathrm{Cu}$ scaffolding onto the particle periphery via direct attachment onto PEG functional groups ( $8 \% \mathrm{ID} / \mathrm{g}$ ).[49] Notably, both of these nanoparticle systems showed greater accumulation in clearance organs ( $\sim 30 \% \mathrm{ID} / \mathrm{g}$ liver, 40 and $20 \% \mathrm{ID} / \mathrm{g}$ spleen) than our highly stable PAA $/ 3\left({ }^{64} \mathrm{Cu}\right)$ system $(8.5 \% \mathrm{ID} / \mathrm{g}$ liver and $5.5 \% \mathrm{ID} / \mathrm{g}$ spleen). The nanogel systems described here also show similar passive tumor uptake to ${ }^{64} \mathrm{Cu}$-doped quantum dot systems designed for multimodal imaging $(12.7 \%$ ID/g).[27] Interestingly, tumor uptake of our nanogels is also greater than that of a recently published PEGylated methacrylate-based ${ }^{64} \mathrm{Cu}$-DOTAcomplexed polymeric nanoparticle targeted with C-type atrial natriuretic factor peptide to CWR22 prostate tumors $(\sim 10 \%$ ID/g).[16, 24] Though tumor uptake values (\% ID/g) differ depending on the tumor cell line and mouse model, tumor uptake of our nanogels appears to compare favorably with that of related systems; receptor-specific targeted nanogel systems may show even greater tumor uptake. Further, their 3-4 fold lower accumulation within the liver and spleen compared with other systems is another critical advantage. Additionally, it should be noted that both PAA $/ 2\left({ }^{64} \mathrm{Cu}\right)$ and PAA $/ 3\left({ }^{64} \mathrm{Cu}\right)$ were significantly retained in the blood through $48 \mathrm{~h}$ (Figures 8 and 9A; 3.6 and $6.6 \%$ ID/g, respectively). More impressively, this blood retention occurred without 
conjugation of PEG to the nanogels, which is routinely performed to increase blood circulation time in vivo. $[16,24,49-52]$

\section{Conclusion}

Here we demonstrate the versatility of nanogels incorporating metal-chelating crosslinkers by applying our platform to PET imaging of primary tumors and metastases. To this end, we screened the chelation stability of nanogels incorporating three crosslinkers based on DTPA, DOTA and NOTA. Experiments in mouse serum indicated that NOTA-based nanogels retained ${ }^{64} \mathrm{Cu}$ most stably; therefore, they were used along with DOTA-based nanogels for in vivo PET/CT imaging of tumor-bearing mice. ${ }^{64} \mathrm{Cu}-\mathrm{NOTA}$ crosslinked nanogels led to better accumulation in tumors, most likely via the enhanced permeability and retention (EPR) effect, as well as lower signal in the liver compared to ${ }^{64} \mathrm{Cu}$-DOTA-crosslinked nanogels, further confirming their better chelation stability. Biodistribution studies also demonstrate greater accumulation of ${ }^{64} \mathrm{Cu}$ in tumors upon administration of NOTA compared to DOTA nanogels (16.6\% vs. $12.9 \%$ injected dose per gram at $48 \mathrm{~h}$ ). In addition, we have shown that ${ }^{64} \mathrm{Cu}$-NOTA-crosslinked nanogels can also detect metastases, in some cases with higher uptake than in subcutaneous tumors.

These promising results suggest that this platform could be expanded for bimodal MRI/PET imaging by using both the ${ }^{64} \mathrm{Cu}-\mathrm{NOTA}$ crosslinkers reported here and the previously reported $\mathrm{Gd}^{3+}$-DOTA crosslinkers, which would combine the high sensitivity of PET with the high resolution of MRI.[3, 13, 53-55] We are currently developing a means of formulating these nanogels from a biodegradable polymer that would be more attractive for clinical translation. We also plan to examine whether functionalization with targeting ligands improves their pharmacokinetics and tumor localization. These nanogels' high chelation stability, high passive tumor uptake, long blood circulation time, and relatively low uptake in the liver and spleen suggest that they represent a promising platform for molecular imaging and drug delivery.

\section{Experimental Procedures}

Materials and methods: Unless otherwise noted, all chemicals were obtained from commercial sources and were used without further purification. All reactions were in oven-dried glassware unless otherwise noted. Flash column chromatography purification was performed using a Teledyne Isco Combiflash Companion with RediSep Rf prepacked silica or C18 columns. Thin layer chromatography was performed with EMD TLC Silica gel $60 \mathrm{~F}_{254}$ glass plates. ${ }^{1} \mathrm{H}$ NMR spectra were acquired using a Varian $600 \mathrm{MHz}$ instrument. Mass determination was performed with a HPLC-MS Agilent 160 Infinity (binary pump, UV-vis 1260 DAD, 6120 Quadrupole LC/MS ESI source) with a RP-18 column. HR-MS measurements were done with an Agilent 6230 ESI-TOF MS. Dynamic light scattering (DLS) and $\zeta$-potential measurements were performed with a Malvern Zetasizer. Radio TLC scans were performed on a Bioscan AR-4000 radio-TLC scanner. PET/CT images were acquired on a Siemens Inveon Preclinical PET/CT system.

Synthesis of 4. N-Boc-1,3-propanediamine $(1.02 \mathrm{~g}$, $5.82 \mathrm{mmol})$ was dissolved in EtOAc $(20 \mathrm{~mL})$, and a solution of $\mathrm{K}_{2} \mathrm{CO}_{3}(12 \mathrm{~g}$, $86.7 \mathrm{mmol})$ in water $(20 \mathrm{~mL})$ was added. The resulting mixture was vigorously stirred at $0{ }^{\circ} \mathrm{C}$ and acryloyl chloride $(1.76 \mathrm{~mL}, 21.7$ $\mathrm{mmol}$ ) was then carefully added and the resulting solution was then allowed to reach room temperature and stirred overnight. Brine and EtOAc were then added and the product was extracted. The organic layers were then dried with $\mathrm{Na}_{2} \mathrm{SO}_{4}$, filtered, and evaporated to give 4 (1.33 g, $100 \%)$. ${ }^{1} \mathrm{H}$ NMR $\left(600 \mathrm{MHz}, \mathrm{CDCl}_{3}, \delta\right): 6.456$ (bs, $\left.1 \mathrm{H}\right), 6.285$ (d, 1H, $J=17.1 \mathrm{~Hz}), 6.129(\mathrm{dd}, 1 \mathrm{H}, J=17.1 \mathrm{~Hz}, 10.1 \mathrm{~Hz}), 5.637(\mathrm{~d}$, $1 \mathrm{H}, \mathrm{J}=10.1 \mathrm{~Hz}), 4.896$ (bs, 1H), $3.373(\mathrm{~m}, 2 \mathrm{H}), 3.190(\mathrm{~m}$, $2 \mathrm{H}), 1.657(\mathrm{~m}, 2 \mathrm{H}), 1.440(\mathrm{~s}, 9 \mathrm{H})$.

Synthesis of 5. N-Boc-protected propane acrylamide 4 (1.33 g, $5.82 \mathrm{mmol})$ was dissolved in DCM (5 $\mathrm{mL})$, and TFA (5 mL) was slowly added under argon. The resulting mixture was vigorously stirred at room temperature. After 30 minutes, deprotection was complete (as confirmed by TLC). After this time, DCM and TFA were evaporated to give 5 as a TFA salt (1.4 g, $100 \%) .{ }^{1} \mathrm{H}{ }^{1} \mathrm{H}$ NMR $\left(600 \mathrm{MHz}, \mathrm{D}_{2} \mathrm{O}, \delta\right): 6.212$ (dd, $1 \mathrm{H}, J=17.1 \mathrm{~Hz}, 10.1 \mathrm{~Hz}), 6.144(\mathrm{~d}, 1 \mathrm{H}, \mathrm{J}=17.1 \mathrm{~Hz}), 5.719$ $(\mathrm{d}, 1 \mathrm{H}, J=10.1 \mathrm{~Hz}), 3.327(\mathrm{t}, 2 \mathrm{H}, J=6.6 \mathrm{~Hz}), 2.973(\mathrm{t}, 2 \mathrm{H}$, $J=7.5 \mathrm{~Hz}), 1.864$ (qt, $2 \mathrm{H}, J=7.5 \mathrm{~Hz}, 6.6 \mathrm{~Hz})$.

Synthesis of DTPA crosslinker 1. N-(3-aminopropyl)acrylamide $\quad 5 \quad(1.4 \quad \mathrm{~g}, \quad 5.82 \mathrm{mmol})$ and DTPA-bisanhydride $(945 \mathrm{mg}, 2.65 \mathrm{mmol})$ were dissolved in DMF $(15 \mathrm{ml})$ under argon. Triethylamine $(8.1 \mathrm{ml}, 58.2 \mathrm{mmol})$ was then added dropwise and the resulting mixture was stirred overnight at room temperature. under argon. After this time, solvents were concentrated and the crude material was purified by reverse phase flash chromatography on C18 with water and methanol as eluents (100:0 to 80:20) to give 1 as a white solid (805 mg, $50 \%) .{ }^{1} \mathrm{H}$ NMR $(600 \mathrm{MHz}$, $\left.\mathrm{D}_{2} \mathrm{O}, \delta\right): 6.207$ (dd, $\left.2 \mathrm{H}, J=17.1 \mathrm{~Hz}, 10.1 \mathrm{~Hz}\right), 6.120(\mathrm{~d}$, $2 \mathrm{H}, \mathrm{J}=17.1 \mathrm{~Hz}), 5.696(\mathrm{~d}, 2 \mathrm{H}, \mathrm{J}=10.1 \mathrm{~Hz}), 3.826(\mathrm{~s}, 4 \mathrm{H})$, $3.695(\mathrm{~s}, 4 \mathrm{H}), 3.668(\mathrm{~s}, 2 \mathrm{H}), 3.336(\mathrm{t}, 4 \mathrm{H}, \mathrm{J}=6.6 \mathrm{~Hz}), 3.242$ $(\mathrm{m}, 12 \mathrm{H}), 1.724(\mathrm{qt}, 4 \mathrm{H}, J=6.6 \mathrm{~Hz})$. HRMS (ESI) $\mathrm{m} / z$ : $[\mathrm{M}+\mathrm{Na}]^{+}$calcd for $\mathrm{C}_{26} \mathrm{H}_{43} \mathrm{~N}_{7} \mathrm{O}_{10} \mathrm{Na}$, 636.2964; found 636.2967.

Synthesis of 6 . Hydroxy- $(\mathrm{tBu})_{4}$ DOTA derivative 5 
was synthesized in 4 steps according to the literature, with a global yield of $10 \%$.[34]

Synthesis of 7. 2,4-Diaminobenzoic acid (3.54 g, $23.2 \mathrm{mmol})$ was dispersed in EtOAc $(140 \mathrm{~mL})$ and a solution of $\mathrm{K}_{2} \mathrm{CO}_{3}(64.3 \mathrm{~g}, 465 \mathrm{mmol})$ in water (140 $\mathrm{mL}$ ) was added. The resulting mixture was vigorously stirred at $0{ }^{\circ} \mathrm{C}$ and acryloyl chloride $(7.6 \mathrm{~mL}, 93.1$ mmol) was then carefully added, resulting in the formation of a light brown precipitate. The reaction mixture was then allowed to reach room temperature, leading to the dissolution of the precipitate. After $1 \mathrm{~h}$ $40 \mathrm{~min}$, the reaction was complete (as confirmed by LC-MS). The organic layer was then discarded and the aqueous layer was acidified with $\mathrm{HCl} 10 \%$, making a precipitate appear at $\mathrm{pH}<4$. EtOAc was then added and the product was extracted. The organic layers were then dried with $\mathrm{MgSO}_{4}$, filtered, and evaporated. The solid residue was then suspended in water, filtered, and washed thoroughly with diethyl ether to give 7 as a gray powder (5.05 g, 84 \%). ${ }^{1} \mathrm{H}$ NMR (600 $\mathrm{MHz}$, dmso- $\left.d_{6}, \delta\right): 9.296$ (s, 1H), 8.944 (s, 2H), 7.371 $(\mathrm{dd}, 2 \mathrm{H}, J=17 \mathrm{~Hz}, 10.5 \mathrm{~Hz}), 7.222(\mathrm{~d}, 2 \mathrm{H}, J=17 \mathrm{~Hz})$, $6.712(\mathrm{~d}, 2 \mathrm{H}, \mathrm{J}=10.5 \mathrm{~Hz})$. ES-MS $m / z:[\mathrm{M}+\mathrm{H}]^{+}$calcd for $\mathrm{C}_{13} \mathrm{H}_{12} \mathrm{~N}_{2} \mathrm{O}_{4}, 261.09$; found 261.0.

Synthesis of DOTA crosslinker 2. Synthesis of crosslinker $\mathbf{2}$ was done in 2 steps from $\mathbf{6}$ and $\mathbf{7}$ and has been previously reported.[13] ${ }^{1} \mathrm{H}$ NMR $(600 \mathrm{MHz}$, $\left.\mathrm{D}_{2} \mathrm{O}, \delta\right): 7.967(\mathrm{~s}, 1 \mathrm{H}), 7.912(\mathrm{~s}, 2 \mathrm{H}), 6.431(\mathrm{dd}, 2 \mathrm{H}$, $J=17.1 \mathrm{~Hz}, 10.1 \mathrm{~Hz}), 6.365(\mathrm{t}, 2 \mathrm{H}, J=17.1 \mathrm{~Hz}), 5.911(\mathrm{~d}$, $2 \mathrm{H}, \mathrm{J}=10.1 \mathrm{~Hz}), 4.605(\mathrm{~m}, 2 \mathrm{H}), 4.25-2.96(\mathrm{~m}, 23 \mathrm{H})$. HRMS (ESI) $m / z$ : $[\mathrm{M}+\mathrm{H}]^{+}$calcd for $\mathrm{C}_{30} \mathrm{H}_{40} \mathrm{~N}_{6} \mathrm{O}_{12}$, 677.2777; found 677.2774.

Synthesis of 9. 3,5-dinitroaniline (2.55 g, 13.9 mmol) was dissolved in a $10 \%$ acetic acid aqueous solution $(150 \mathrm{~mL})$ and a solution of Fmoc chloride $(3.78 \mathrm{~g}, 14.6 \mathrm{mmol})$ in THF $(150 \mathrm{~mL})$ was added under argon. The resulting mixture was stirred at room temperature overnight. After this time, THF was evaporated and water and EtOAc were added and the product was extracted. The organic layers were then dried with $\mathrm{MgSO}_{4}$, filtered, and evaporated. The solid residue was taken up in a mixture of EtOAc and hexanes and the resulting yellow suspension was filtered, and washed thoroughly with EtOAc/hexanes to give 9 as a yellow powder $(2.2 \mathrm{~g}, 39 \%) .{ }^{1} \mathrm{H}$ NMR (600 MHz, dmso- $\left.d_{6}, \delta\right): 10.657(\mathrm{~s}, 1 \mathrm{H}), 8.726$ (bs, 2H), $8.453(\mathrm{t}, 1 \mathrm{H}, \mathrm{J}=2.2 \mathrm{~Hz}), 7.926(\mathrm{~d}, 2 \mathrm{H}, \mathrm{J}=7.5 \mathrm{~Hz}), 7.762(\mathrm{~d}$, $2 \mathrm{H}, J=7.5 \mathrm{~Hz}), 7.443(\mathrm{t}, 2 \mathrm{H}, J=7.5 \mathrm{~Hz}), 7.372(\mathrm{t}, 2 \mathrm{H}$, $J=7.5 \mathrm{~Hz}), 4.635(\mathrm{~d}, 2 \mathrm{H}, J=6.6 \mathrm{~Hz}), 4.369(\mathrm{t}, 1 \mathrm{H}, J=6.6$ $\mathrm{Hz}$ ). HRMS (ESI) $m / z:[\mathrm{M}+\mathrm{Na}]^{+}$calcd for $\mathrm{C}_{21} \mathrm{H}_{15} \mathrm{~N}_{3} \mathrm{O}_{6} \mathrm{Na}$, 428.0853; found 428.0850 .

Synthesis of 10. Fmoc-protected dinitro aniline 9 (203 $\mathrm{mg}, 0.5 \mathrm{mmol})$ and tin chloride dihydrate (678 $\mathrm{mg}, 3 \mathrm{mmol}$ ) were placed under argon and $\mathrm{EtOH}(5$ $\mathrm{mL}$ ) was added. The resulting mixture was stirred at
$70{ }^{\circ} \mathrm{C}$ for $3 \mathrm{~h} 30$. After this time, an aqueous solution of $\mathrm{NaHCO}_{3}$ was added to neutralize $\mathrm{HCl}$ until the $\mathrm{pH}$ reaches 7-8. $\mathrm{H}_{2} \mathrm{O}$ and EtOAc were then added to the mixture and the product was extracted. The organic layers were then dried with $\mathrm{MgSO}_{4}$, filtered, and evaporated to give $\mathbf{1 0}$ as a crispy grey solid (172 mg, $100 \%) .{ }^{1} \mathrm{H}$ NMR $\left(600 \mathrm{MHz}, \mathrm{CDCl}_{3}, \delta\right): 7.729$ (d, 2H, $J=7.5 \mathrm{~Hz}), 7.552(\mathrm{~d}, 2 \mathrm{H}, J=7.5 \mathrm{~Hz}), 7.355(\mathrm{t}, 2 \mathrm{H}, J=7.5$ $\mathrm{Hz}), 7.268$ (t, 2H, J=7.5 Hz), 6.985 (bs, 1H), 6.004 (bs, $2 \mathrm{H}), 5.492(\mathrm{~s}, 1 \mathrm{H}), 4.501(\mathrm{~d}, 2 \mathrm{H}, J=5.7 \mathrm{~Hz}), 4.175(\mathrm{t}, 1 \mathrm{H}$, $J=5.7 \mathrm{~Hz}), 3.395$ (bs, 4H). HRMS (ESI) $m / z:[\mathrm{M}+\mathrm{Na}]^{+}$ calcd for $\mathrm{C}_{21} \mathrm{H}_{19} \mathrm{~N}_{3} \mathrm{O}_{2} \mathrm{Na}$, 368.1369; found 368.1364.

Synthesis of 11. Fmoc-protected diamino aniline 10 (172 mg, $0.5 \mathrm{mmol})$ was dissolved in EtOAc $(5 \mathrm{~mL})$ and a solution of $\mathrm{K}_{2} \mathrm{CO}_{3}(1.4 \mathrm{~g}, 10 \mathrm{mmol})$ in water (5 $\mathrm{mL}$ ) was added. The resulting mixture was vigorously stirred at $0{ }^{\circ} \mathrm{C}$ for $10 \mathrm{~min}$ and acryloyl chloride (0.16 $\mathrm{mL}, 2 \mathrm{mmol}$ ) was then carefully added and the resulting mixture was stirred for $10 \mathrm{~min}$ at $0{ }^{\circ} \mathrm{C}$. After this time, the reaction mixture was allowed to reach room temperature. After $30 \mathrm{~min}$ at room temperature, the reaction was complete (as confirmed by LC-MS), $\mathrm{H}_{2} \mathrm{O}$ and EtOAc were added to the mixture and the product was extracted. The organic layers were then dried with $\mathrm{MgSO}_{4}$, filtered, and evaporated to give 11 as a pale yellow solid (236 mg, $100 \%) .{ }^{1} \mathrm{H}$ NMR (600 $\mathrm{MHz}$, dmso- $\left.d_{6}, \delta\right): 10.149$ (s, 2H), 9.849 (1, 2H), 7.912 (d, 2H, J=7.5 Hz), 7.818 (bs, 1H), 7.778 (d, 2H, J=7.5 $\mathrm{Hz}), 7.633$ (bs, 2H), $7.433(\mathrm{t}, 2 \mathrm{H}, J=7.5 \mathrm{~Hz}), 7.356(\mathrm{t}, 2 \mathrm{H}$, $J=7.5 \mathrm{~Hz}), 6.46(\mathrm{dd}, 2 \mathrm{H}, J=17.1 \mathrm{~Hz}, 10.1 \mathrm{~Hz}), 6.246(\mathrm{dd}$, 2H, J=17.1 Hz, $1.8 \mathrm{~Hz}), 5.732$ (dd, 2H, J=10.1 Hz, 1.8 $\mathrm{Hz}), 4.415(\mathrm{~d}, 2 \mathrm{H}, J=7.0 \mathrm{~Hz}), 4.307(\mathrm{t}, 1 \mathrm{H}, J=7.0 \mathrm{~Hz})$. HRMS (ESI) $m / z$ : $[\mathrm{M}+\mathrm{Na}]^{+}$calcd for $\mathrm{C}_{27} \mathrm{H}_{23} \mathrm{~N}_{3} \mathrm{O}_{4} \mathrm{Na}$, 476.1581; found 476.1575 .

Synthesis of 12. Fmoc-protected bisacrylamide aniline 11 (236 mg, $0.5 \mathrm{mmol})$ was dissolved in dry DMF $(1 \mathrm{~mL})$ and a solution of piperidine $(50 \mu \mathrm{L}, 0.5$ $\mathrm{mmol})$ in dry DMF $(0.8 \mathrm{~mL})$ was added. The resulting mixture was stirred at room temperature under argon for one hour. After this time, more piperidine $(12.5 \mu \mathrm{L}$, $0.125 \mathrm{mmol})$ in DMF $(0.2 \mathrm{~mL})$ was added. After one additional hour of stirring, the solvents were evaporated under vacuum and the solid residue was purified by Combiflash, by using a $12 \mathrm{~g} \mathrm{SiO}_{2}$ column and $\mathrm{DCM} / \mathrm{MeOH}$ as the eluent mixture (100:0 to 85:15) to give 12 as a pale yellow solid (60 mg, 52\%). ${ }^{1} \mathrm{H}$ NMR $\left(600 \mathrm{MHz}, \mathrm{dmso}-d_{6}, \delta\right): 9.826(\mathrm{~s}, 2 \mathrm{H}), 7.165$ (s, $\left.1 \mathrm{H}\right)$, $6.725(\mathrm{~s}, 2 \mathrm{H}), 6.431(\mathrm{dd}, 2 \mathrm{H}, J=17.1 \mathrm{~Hz}, 10.1 \mathrm{~Hz}), 6.202$ $(\mathrm{dd}, 2 \mathrm{H}, J=17.1 \mathrm{~Hz}, 1.8 \mathrm{~Hz}), 5.688(\mathrm{dd}, 2 \mathrm{H}, J=10.1 \mathrm{~Hz}$, $1.8 \mathrm{~Hz}), 5.138(\mathrm{~s}, 2 \mathrm{H})$. HRMS (ESI) $\mathrm{m} / z:[\mathrm{M}+\mathrm{H}]^{+}$calcd for $\mathrm{C}_{12} \mathrm{H}_{13} \mathrm{~N}_{3} \mathrm{O}_{2}$, 254.0896; found 254.0900.

Synthesis of NOTA crosslinker 3. 3,5-bisacrylamide aniline 12 (10.3 mg, $0.045 \mathrm{mmol})$ and $p$-benzyl isothiocyanate NOTA ( $25 \mathrm{mg}, 0.045 \mathrm{mmol}$ ) were dissolved in dry $\mathrm{MeOH}(4 \mathrm{~mL})$ and dry $\mathrm{Et}_{3} \mathrm{~N}(62 \mu \mathrm{L}, 0.45 \mathrm{mmol})$ 
was added. The resulting mixture was stirred at room temperature under argon for 48 hours. After this time, solvents were evaporated under vacuum and the solid residue was purified by Reverse Phase Combiflash, by using a High Performance $5.5 \mathrm{~g}$ C18 column and $\mathrm{H}_{2} \mathrm{O}$ as the eluent. The product 3 was obtained after lyophilization as a fluffy white solid (18 mg, 59\%). ${ }^{1} \mathrm{H}$ NMR (600 MHz, $\left.\mathrm{D}_{2} \mathrm{O}, \delta\right): 7.621$ (bd, $\left.1 \mathrm{H}\right)$, $7.322(\mathrm{~m}, 4 \mathrm{H}), 7.269(\mathrm{~d}, 2 \mathrm{H}), 6.406(\mathrm{dd}, 2 \mathrm{H}, \mathrm{J}=16.7 \mathrm{~Hz}$, $10.1 \mathrm{~Hz}), 6.338$ (d, 2H, J=16.7 Hz), 5.88 (d, 2H, J=10.1 $\mathrm{Hz}, 1.8 \mathrm{~Hz}), 3.754-2.679$ ppm (m, 19H). HRMS (ESI) $m / z:[\mathrm{M}+\mathrm{H}]^{+}$calcd for $\mathrm{C}_{32} \mathrm{H}_{39} \mathrm{~N}_{7} \mathrm{O}_{8} \mathrm{~S}, 704.2473$; found 704.2466 .

Nanogel preparation. Nanogels at $1.2 \%$ crosslinking density were formed by dissolving $6.9,6.8$, or 6.8 $\mathrm{mg}(10.0 \mu \mathrm{mol})$ of $\mathbf{1}, \mathbf{2}$ or $\mathbf{3}$, respectively, together with $61.3 \mathrm{mg}$ of acrylamide in $250 \mu \mathrm{L}$ of $10 \mathrm{mM}$ Tris- $\mathrm{HCl}$ (pH 8), which was then added into $11 \mathrm{ml}$ of $9 \%$ AOT in hexane. After vortexing for $1 \mathrm{~min}, 32 \mu \mathrm{L}$ of $50 \%$ APS in $10 \mathrm{mM}$ Tris- $\mathrm{HCl}(\mathrm{pH} 8)$ was added. The reaction mixture was vortexed for $1 \mathrm{~min}$, and then filtered through a $0.1 \mu \mathrm{m}$ PVDF filter three times. After portionwise addition of $500 \mu \mathrm{L}$ of $5 \%$ TMEDA in hexane $(10 \mu \mathrm{L} \times 50)$, the particle solution was left on a shaker at $60 \mathrm{rpm}$ for $30 \mathrm{~min}$, followed by removal of hexane by rotary evaporation at $40{ }^{\circ} \mathrm{C}$. Nanogels were washed with acetone $(10 \mathrm{~mL} \times 3)$ and collected each time by centrifugation at $5,000 \mathrm{rpm}$ for $5 \mathrm{~min}$. The white precipitate was then resuspended in $2 \mathrm{~mL}$ of $1 \mathrm{X}$ PBS buffer, pH 7.4.

Dynamic light scattering (DLS) measurements. 20 $\mu \mathrm{L}$ of gel particle solution was added to $200 \mu \mathrm{L}$ of $1 \mathrm{X}$ PBS ( $\mathrm{pH}$ 7.4) for DLS measurement using a Malvern Zetasizer.

Zeta-potential measurements. For unchelated nanogels, $20 \mu \mathrm{L}$ of gel particle solution was added to $200 \mu \mathrm{L}$ of $\mathrm{H}_{2} \mathrm{O}+0.01 \% \mathrm{Et}_{3} \mathrm{~N}(\mathrm{pH} 8)$ for $\zeta$-potential measurement using a Malvern Zetasizer. For $\mathrm{Cu}^{2+}$-chelated nanogels, $\mathrm{Cu}_{2} \mathrm{SO}_{4}$ (1.5 eq.) was added to a solution of PAA nanogels $(100 \mu \mathrm{g})$ in $\mathrm{H}_{2} \mathrm{O}+0.01 \%$ $\mathrm{Et}_{3} \mathrm{~N}(\mathrm{pH}$ ) at a nanogel concentration of $1 \mathrm{mg} / \mathrm{mL}$ and allowed to incubate at $70^{\circ} \mathrm{C}$ for $2 \mathrm{~h}$. Following the incubation, nanogels were diluted 1:10 in $\mathrm{H}_{2} \mathrm{O}+0.01 \%$ $\mathrm{Et}_{3} \mathrm{~N}$ and placed inside an Amicon Ultra-centrifugal filtration unit (100 KDa MW cutoff) and centrifuged at $14000 \times \mathrm{g}$ for $10 \mathrm{~min}$ at $20^{\circ} \mathrm{C}$. The nanogels were then washed twice with fresh sterile PBS and centrifuged with the before-mentioned parameters. The $\zeta$-potentials of the resulting $\mathrm{Cu}^{2+}$-chelated nanogels were then measured.

Nanogel labeling/stability studies. PAA nanogels $(100 \mu \mathrm{g})$ was combined with $37 \mathrm{MBq}(1 \mathrm{mCi})$ of ${ }^{64} \mathrm{Cu}$ in sterile PBS ( $\mathrm{pH} 7.4)$ at a nanogel concentration of 1 $\mathrm{mg} / \mathrm{mL}$ and allowed to incubate at $70{ }^{\circ} \mathrm{C}$ for $2 \mathrm{~h}$. Following the incubation, nanogels were diluted $10 \mathrm{x}$ in sterile PBS and placed inside a Amicon Ultra centrifugal filtration unit (3000 Da MW cutoff) and centrifuged at $4000 \times \mathrm{g}$ for $30 \mathrm{~min}$ at $4{ }^{\circ} \mathrm{C}$. The nanogels were then washed twice with fresh sterile PBS and centrifuged with the before mentioned parameters. Gels were then added to 100x equivalents of EDTA in PBS based on crosslinker concentration in solution (1.2 molar \%) and incubated for varying times at 37 ${ }^{\circ} \mathrm{C}$. Aliquots $(2 \mu \mathrm{L})$ were analyzed by TLC using ITLC-SG glass microfiber silica impregnated chromatography paper, with 75:25 $\mathrm{MeOH}: \mathrm{NH}_{4} \mathrm{OAc}$ as the mobile phase. The TLC strips were analyzed for radioactivity on a Bioscan AR-2000, and the concentrations of ${ }^{64} \mathrm{Cu}$-EDTA and ${ }^{64} \mathrm{Cu}$-nanogel were quantified by Winscan software (Bioscan).

Animal studies. All animal studies were performed in compliance with guidelines that were approved by the University of Pittsburgh Institutional Animal Care and Use Committee. For primary tumor imaging and biodistribution studies, BALB/c mice were injected with $5 \times 10^{5} 4 \mathrm{~T} 1$ mouse mammary carcinoma cells in the right flank using a 29 gauge syringe while under isoflurane anesthesia (2.5\%; flow rate $2 \mathrm{~L} / \mathrm{min}$ ). Tumors were allowed to grow for three weeks before experiments were conducted. For metastasis imaging studies, BALB/c mice were injected with $1 \times 10^{5}$ 4T1-luc mouse mammary carcinoma cells via the tail vein. Metastasis formation was monitored via bioluminescence imaging ( $1 \mathrm{~min}$ acquisitions under $2 \%$ isoflurane anesthesia with an oxygen flow rate of $2 \mathrm{~L} / \mathrm{min})$. PET imaging was performed 26 days after cell injection.

Small animal PET/CT Imaging. Mice were anesthetized under a heat lamp using $2.5 \%$ isoflurane under oxygen with at a flow rate of $2 \mathrm{~L} / \mathrm{min}$. PAA $/ 2\left({ }^{64} \mathrm{Cu}\right), \mathrm{PAA} / 3\left({ }^{64} \mathrm{Cu}\right)$ or free ${ }^{64} \mathrm{Cu}((\sim 160-190$ $\mu \mathrm{Ci}$; diluted in $100 \mu \mathrm{L}$ sterile PBS; pH 7.4) was injected via the tail vein using a 29 gauge insulin syringe. Images of anesthetized mice (2-2.5\% isoflurane) were acquired on a Siemens Inveon Preclinical PET/CT at 4,24 , and $48 \mathrm{~h}$ post probe injection. Excreted ${ }^{64} \mathrm{Cu}$ was not taken into consideration. PET images were acquired for 900 seconds and reconstructed using the 2DFBP algorithm with scatter correction for image analysis and the OSEM3D algorithm for image display. The CT images consisted of 120 images $(140 \mathrm{~ms}$ with $4 \times 4$ binning and low magnification) over a 220 degree imaging arc. Cobra Reconstruction software was applied with a downsample factor of 4 . ROI analyses of PET images were performed by overlaying the PET and CT images using the Inveon Research Workplace (IRW) software. ROIs were drawn on the tumor (transaxial slices) and muscle (coronal slices) using the CT images as a guide. The ROI was converted to a volume-of-interest (VOI) using the "in- 
terpolation" tool and values from the PET image were reported as average SUV over the VOI. ROI values were plotted and two-way ANOVA tests were performed using Prism 5 (GraphPad). For image display, maximum intensity projections (MIPs) of the PET/CT overlay were produced using IRW, PET images were windowed to remove background signal, and windowing was also changed over time relative to the half-life of the ${ }^{64} \mathrm{Cu}$ isotope (nCi/cc units). CT images were windowed to eliminate all soft tissue from the image.

Biodistribution. Mice were anesthetized under a heat lamp using $2.5 \%$ isoflurane under oxygen with at a flow rate of $2 \mathrm{~L} / \mathrm{min}$. PAA $/ 2\left({ }^{64} \mathrm{Cu}\right)$ or PAA $/ 3\left({ }^{64} \mathrm{Cu}\right)$ $(\sim 50 \mu \mathrm{Ci}$; diluted in $100 \mu \mathrm{L}$ sterile PBS; $\mathrm{pH}$ 7.4) was injected via the tail vein using a 29 gauge insulin syringe. Mice were euthanized via cervical dislocation under isoflurane anesthesia at 4, 24, and $48 \mathrm{~h}$ post-injection ( $\mathrm{n}=5$ for each group and time cohort). Organs (blood, heart, lungs, liver, spleen, pancreas, small intestine, large intestine, muscle, brain, and tumor) were collected, weighed, and counted on a Wizard $^{2}$ gamma counter (Perkin Elmer). Standards were prepared, weighed, and counted along with the samples in order to calculate \% ID/g values.

\section{Supplementary Material}

Size distribution of PAA/1, PAA/ 2 and PAA/ 3 as measured by DLS (Figure S1). Stability measurements of the ${ }^{64} \mathrm{Cu}$-chelated nanogels in PBS, mouse serum and in presence of EDTA (Figure S2). Average \%ID/g values obtained through ROI analysis (Table S1).

http://www.thno.org/v05p0277s1.pdf

\section{Abbreviations}

DCM: dichloromethane; DCC: N,N-dicyclohexylcarbodiimide; DLS: dynamic light scattering; DMAP: 4-dimethylaminopyridine; DMF: dimethylformamide; DOTA: $\quad$ 1,4,7,10-tetraazacyclododecane-1,4,7,10tetraacetic acid; DTPA: diethylene triamine pentaacetic acid; EDTA: ethylenediaminetetraacetic acid; HRMS: high resolution mass spectrometry; LC-MS: liquid chromatography-mass spectrometry; $\mathrm{MeOH}$ : methanol; NMR: nuclear magnetic resonance; NOTA: 1,4,7-triazacyclononane-triacetic acid; ESI: electrospray ionization; ES-MS: electrospray mass spectrometry; PAA: polyacrylamide; PET/CT: positron emission tomography-computed tomography; TLC: thin layer chromatography.

\section{Acknowledgment}

NMR data was acquired at the UCSD Skaggs School of Pharmacy and Pharmaceutical Sciences NMR Facility.

\section{Funding Sources}

This research was made possible by an NIH New Innovator Award (DP 2OD006499), NSF (1006081), King Abdulaziz City for Science and Technology (through the KACST-UCSD Center of Excellence in Nanomedicine and Engineering), and the Office of Science (BER) U.S. Department of Energy (DE-SC0008833). University of Pittsburgh Cancer Institute (UPCI) shared resources (In Vivo Imaging Facility) were used in this research, and this facility is supported in part by award NCI P30CA047904.

\section{Author Contributions}

The manuscript was written through contributions of all authors. All authors have given approval to the final version of the manuscript.

\section{Competing Interests}

The authors have declared that no competing interest exists.

\section{References}

1. Caravan P, Begley TP. Metals in Medicine: Imaging Agents. Wiley Encyclopedia of Chemical Biology: John Wiley \& Sons, Inc.; 2007.

2. Caravan P, Ellison JJ, McMurry TJ, Lauffer RB. Gadolinium(III) chelates as MRI contrast agents: Structure, dynamics, and applications. Chem Rev. 1999; 99: 2293-352.

3. Caravan P. Strategies for increasing the sensitivity of gadolinium based MRI contrast agents. Chem Soc Rev. 2006; 35: 512-23.

4. Anderson CJ, Welch MJ. Radiometal labeled agents (non-technetium) for diagnostic imaging. Chem Rev. 1999; 99: 2219-34.

5. Anderson CJ, Ferdani R. Copper-64 Radiopharmaceuticals for PET Imaging of Cancer: Advances in Preclinical and Clinical Research. Cancer Biother Radiopharm. 2009; 24: 379-93.

6. Yu SB, Watson AD. Metal-based X-ray contrast media. Chem Rev. 1999; 99 : 2353-77.

7. Lemieux P, Vinogradov SV, Gebhart CL, Guerin N, Paradis G, Nguyen HK, et al. Block and graft copolymers and Nanogel (TM) copolymer networks for DNA delivery into cell. J Drug Target. 2000; 8: 91-105.

8. Kabanov AV, Vinogradov SV. Nanogels as Pharmaceutical Carriers: Finite Networks of Infinite Capabilities. Angew Chem Int Ed Engl. 2009; 48: 5418-29.

9. Bronich TK, Vinogradov SV, Kabanov AV. Interaction of nanosized copolymer networks with oppositely charged amphiphilic molecules. Nano Lett. 2001; 1: 535-40.

10. Missirlis D, Kawamura R, Tirelli N, Hubbell JA. Doxorubicin encapsulation and diffusional release from stable, polymeric, hydrogel nanoparticles. Eur J Pharm Sci. 2006; 29: 120-9.

11. Kwon YJ, Standley SM, Goh SL, Frechet JMJ. Enhanced antigen presentation and immunostimulation of dendritic cells using acid-degradable cationic nanoparticles. J Control Release. 2005; 105: 199-212.

12. Standley SM, Mende I, Goh SL, Kwon YJ, Beaudette TT, Engleman EG, et al. Incorporation of $\mathrm{CpG}$ oligonucleotide ligand into protein-loaded particle vaccines promotes antigen-specific CD8 T-cell immunity. Bioconj Chem. 2007; 18: 77-83.

13. Lux J, Chan MN, Elst LV, Schopf E, Mahmoud E, Laurent S, et al. Metal chelating crosslinkers form nanogels with high chelation stability. J Mater Chem B. 2013; 1: 6359-64

14. Rossin R, Pan DPJ, Qi K, Turner JL, Sun XK, Wooley KL, et al. Cu-64-labeled folate-conjugated shell cross-linked nanoparticles for tumor imaging and radiotherapy: Synthesis, radiolabeling, and biologic evaluation. J Nucl Med. 2005; 46: $1210-8$

15. Xu JQ, Sun GR, Rossin R, Hagooly A, Li ZC, Fukukawa K, et al. Labeling of polymer nanostructures for medical imaging: Importance of cross-linking extent, spacer length, and charge density. Macromolecules. 2007; 40: 2971-3.

16. Pressly ED, Rossin R, Hagooly A, Fukukawa KI, Messmore BW, Welch MJ, et al. Structural effects on the biodistribution and positron emission tomography (PET) imaging of well-defined Cu-64-labeled nanoparticles comprised of amphiphilic block graft copolymers. Biomacromolecules. 2007; 8: 3126-34.

17. Nahrendorf $M$, Zhang HW, Hembrador S, Panizzi P, Sosnovik DE, Aikawa E, et al. Nanoparticle PET-CT imaging of macrophages in inflammatory atherosclerosis. Circulation. 2008; 117: 379-87. 
18. Rossin R, Muro S, Welch MJ, Muzykantov VR, Schuster DP. In vivo imaging of $\mathrm{Cu}-64$-labeled polymer nanoparticles targeted to the lung endothelium. J Nucl Med. 2008; 49: 103-11.

19. Zhou M, Zhang R, Huang MA, Lu W, Song SL, Melancon MP, et al. A Chelator-Free Multifunctional [Cu-64]CuS Nanoparticle Platform for Simultaneous Micro-PET/CT Imaging and Photothermal Ablation Therapy. J Am Chem Soc. 2010; 132: 15351-8.

20. Yang XQ, Hong H, Grailer JJ, Rowland IJ, Javadi A, Hurley SA, et al. cRGD-functionalized, DOX-conjugated, and Cu-64-labeled superparamagnetic iron oxide nanoparticles for targeted anticancer drug delivery and PET/MR imaging. Biomaterials. 2011; 32: 4151-60.

21. Shokeen M, Pressly ED, Hagooly A, Zheleznyak A, Ramos N, Fiamengo AL, et al. Evaluation of Multivalent, Functional Polymeric Nanoparticles for Imaging Applications. ACS Nano. 2011; 5: 738-47.

22. Zeng DX, Lee NS, Liu YJ, Zhou D, Dence CS, Wooley KL, et al. Cu-64 Core-Labeled Nanoparticles with High Specific Activity via Metal-Free Click Chemistry. ACS Nano. 2012; 6: 5209-19.

23. Lee DE, Na JH, Lee S, Kang CM, Kim HN, Han SJ, et al. Facile Method To Radiolabel Glycol Chitosan Nanoparticles with $\mathrm{Cu}-64$ via Copper-Free Click Chemistry for MicroPET Imaging. Mol Pharm. 2013; 10: 2190-8.

24. Pressly ED, Pierce RA, Connal LA, Hawker CJ, Liu YJ. Nanoparticle PET/CT Imaging of Natriuretic Peptide Clearance Receptor in Prostate Cancer. Bioconj Chem. 2013; 24: 196-204.

25. Lee S, Kang SW, Ryu JH, Na JH, Lee DE, Han SJ, et al. Tumor-Homing Glycol Chitosan-Based Optical/PET Dual Imaging Nanoprobe for Cancer Diagnosis. Bioconj Chem. 2014; 25: 601-10.

26. Zhao YF, Sultan D, Detering L, Cho SH, Sun GR, Pierce R, et al. Copper-64-Alloyed Gold Nanoparticles for Cancer Imaging: Improved Radiolabel Stability and Diagnostic Accuracy. Angew Chem Int Ed Engl. 2014; 53: $156-9$.

27. Sun XL, Huang XL, Guo JX, Zhu WL, Ding Y, Niu G, et al. Self-illuminating Cu-64-Doped CdSe/ZnS Nanocrystals for in Vivo Tumor Imaging. J Am Chem Soc. 2014; 136: 1706-9.

28. Jensen AI, Binderup T, Kumar EKP, Kjaer A, Rasmussen PH, Andresen TL. Positron Emission Tomography Based Analysis of Long-Circulating Cross-Linked Triblock Polymeric Micelles in a U87MG Mouse Xenograft Model and Comparison of DOTA and CB-TE2A as Chelators of Copper-64. Biomacromolecules. 2014; 15: 1625-33.

29. Haque MM, Im HY, Seo JE, Hasan M, Woo K, Kwon OS. Acute toxicity and tissue distribution of CdSe/CdS-MPA quantum dots after repeated intraperitoneal injection to mice. J Appl Toxicol. 2013; 33: 940-50.

30. Singh S, Bingol B, Morgenroth A, Mottaghy FM, Moller M, Schmaljohann J. Radiolabeled Nanogels for Nuclear Molecular Imaging. Macromol Rapid Comm. 2013; 34: 562-7.

31. Alexis F, Pridgen E, Molnar LK, Farokhzad OC. Factors affecting the clearance and biodistribution of polymeric nanoparticles. Mol Pharm. 2008; 5: 505-15.

32. Moi MK, Meares CF, Mccall MJ, Cole WC, Denardo SJ. Copper-Chelates as Probes of Biological-Systems - Stable Copper-Complexes with a Macrocyclic Bifunctional Chelating Agent. Anal Biochem. 1985; 148: 249-53.

33. Anderson CJ, Rocque PA, Weinheimer CJ, Welch MJ. Evaluation of Copper-Labeled Bifunctional Chelate Albumin Conjugates for Blood Pool Imaging. Nucl Med Biol. 1993; 20: 461-7.

34. Vanasschen C, Bouslimani N, Thonon D, Desreux JF. Gadolinium DOTA Chelates Featuring Alkyne Groups Directly Grafted on the Tetraaza Macrocyclic Ring: Synthesis, Relaxation Properties, "Click" Reaction, and High-Relaxivity Micelles. Inorg Chem. 2011; 50: 8946-58.

35. Christensen LH, Breiting VB, Aasted A, Jorgensen A, Kebuladze I. Long-term effects of polyacrylamide hydrogel on human breast tissue. Plast Reconstr Surg. 2003; 111: 1883-90.

36. Berndt WO, Bergfeld WF, Boutwell RK, Carlton WW, Hoffmann DK, Schroeter AL, et al. Final Report on the Safety Assessment of Polyacrylamide. J Am Coll Toxicol. 1991; 10: 193-203.

37. Andersen FA. Amended final report on the safety assessment of polyacrylamide and acrylamide residues in cosmetics. Int J Toxicol. 2005; 24 : 21-50.

38. Sjoholm I, Edman P. Acrylic Microspheres Invivo .1. Distribution and Elimination of Polyacrylamide Microparticles after Intravenous and Intra-Peritoneal Injection in Mouse and Rat. J Pharmacol Exp Ther. 1979; 211: 656-62.

39. Gupta A, Wang S, Marko A, Joshi P, Ethirajan M, Chen YH, et al. Polyacrylamide-Based Biocompatible Nanoplatform Enhances the Tumor Uptake, PET/fluorescence Imaging and Anticancer Activity of a Chlorophyll Analog. Theranostics. 2014; 4: 614-28.

40. Ait-Mohand S, Fournier P, Dumulon-Perreault V, Kiefer GE, Jurek P, Ferreira $\mathrm{CL}$, et al. Evaluation of Cu-64-Labeled Bifunctional Chelate-Bombesin Conjugates. Bioconj Chem. 2011; 22: 1729-35

41. Rex GC, Schlick S. Binding of Cu-2+ in Polyacrylamide Gels - an Electron-Spin Resonance Study. J Phys Chem. 1985; 89: 3598-601.

42. Jorgensen JT, Persson M, Madsen J, Kjaer A. High tumor uptake of Cu-64: Implications for molecular imaging of tumor characteristics with copper-based PET tracers. Nucl Med Biol. 2013; 40: 345-50

43. Rashid OM, Nagahashi M, Ramachandran S, Dumur CI, Schaum JC, Yamada A, et al. Is tail vein injection a relevant breast cancer lung metastasis model? J Thorac Dis. 2013; 5: 385-92.
44. Boswell CA, Sun $\mathrm{X}$, Niu W, Weisman GR, Wong EH, Rheingold AL, et al. Comparative in vivo stability of copper-64-labeled cross-bridged and conventional tetraazamacrocyclic complexes. J Med Chem. 2004; 47: 1465-74.

45. Sun XK, Wuest M, Weisman GR, Wong EH, Reed DP, Boswell CA, et al. Radiolabeling and in vivo behavior of copper-64-labeled cross-bridged cyclam ligands. J Med Chem. 2002; 45: 469-77.

46. Ping Li W, Meyer LA, Capretto DA, Sherman CD, Anderson CJ. Receptor-binding, biodistribution, and metabolism studies of 64Cu-DOTA-cetuximab, a PET-imaging agent for epidermal growth-factor receptor-positive tumors. Cancer Biother Radiopharm. 2008; 23: 158-71.

47. Fani M, Del Pozzo L, Abiraj K, Mansi R, Tamma ML, Cescato R, et al. PET of somatostatin receptor-positive tumors using $64 \mathrm{Cu}$ - and $68 \mathrm{Ga}$-somatostatin antagonists: the chelate makes the difference. J Nucl Med. 2011; 52: 1110-8.

48. Roosenburg S, Laverman P, Joosten L, Cooper MS, Kolenc-Peitl PK, Foster JM, et al. PET and SPECT Imaging of a Radiolabeled Minigastrin Analogue Conjugated with DOTA, NOTA, and NODAGA and Labeled with $\mathrm{Cu}, \mathrm{Ga}$, and In. Mol Pharm. 2014.

49. Wang YC, Liu YJ, Luehmann $H$, Xia XH, Brown P, Jarreau C, et al. Evaluating the Pharmacokinetics and In Vivo Cancer Targeting Capability of Au Nanocages by Positron Emission Tomography Imaging. ACS Nano. 2012; 6: 5880-8.

50. Fukukawa KI, Rossin R, Hagooly A, Pressly ED, Hunt JN, Messmore BW, et al. Synthesis and characterization of core-shell star copolymers for in vivo PET imaging applications. Biomacromolecules. 2008; 9: 1329-39.

51. Glaus C, Rossin R, Welch MJ, Bao G. In Vivo Evaluation of Cu-64-Labeled Magnetic Nanoparticles as a Dual-Modality PET/MR Imaging Agent. Bioconj Chem. 2010; 21: 715-22.

52. Zhang ZY, Liu YJ, Jarreau C, Welch MJ, Taylor JSA. Nucleic acid-directed self-assembly of multifunctional gold nanoparticle imaging agents. Biomater Sci. 2013; 1: 1055-64.

53. Werner EJ, Datta A, Jocher CI, Raymond KN. High-Relaxivity MRI Contrast Agents: Where Coordination Chemistry Meets Medical Imaging. Angew Chem Int Ed Engl. 2008; 47: 8568-80

54. Manus LM, Strauch RC, Hung AH, Eckermann AL, Meade TJ. Analytical Methods for Characterizing Magnetic Resonance Probes. Anal Chem. 2012; 84: 6278-87.

55. Weissleder R, Pittet MJ. Imaging in the era of molecular oncology. Nature. 2008; 452: 580-9. 